\title{
The Justice of Inequality: Argumentation Ethics and Radical Non-Aggression
}

By: Daniel Gibbs

Abstract: Questions of inequality of wealth frequently arise during times of economic hardship. The stagnant recovery from the 2008 global financial crisis is no exception. Many are quick to condemn inequality as an unjust social phenomenon. This article considers the ethical status of such claims by examining whether inequality is fair or not. Using a neo-Kantian framework first put forward by Hans-Hermann Hoppe, the paper elucidates the presuppositions implied by human action and uses these as a basis for political rights. Once inviolable rights to ownership of one's person and property are established, it follows that income inequality in the absence of coercion is fair. However, since such a condition does not describe modern society, little can be immediately said about the justice of current levels of inequality.

\section{Introduction}

Political philosophy is the subset of ethics that deals with how two or more humans ought to interact with each other in society. It says nothing about how individuals should act in isolation. It answers social questions by showing us what is fair, just, and moral. Generally, the task of the political philosopher is to discover under what conditions it is ethically justifiable for humans to coerce or use violence against other humans. This question is prior to all man made laws, as coercion is required in order to enforce these positive decrees.

In order to evaluate the ethical status of a social phenomenon, we must evaluate the human actions that bring it about. In the wake of the stagnant recovery from the 2008 financial crisis, income inequality been subject to an increasing amount of scrutiny. While inequality may give rise to revulsion inspired by sympathy, when considering what, if any action to pursue in response to this feeling, we must not eschew ethical considerations. We must therefore evaluate the ethical basis for property ownership before we may embark upon schemes to alter its distribution.

In this paper, I will present and elaborate upon a little-known ethical theory developed primarily by Hans-Hermann Hoppe. Taking a neo-Kantian deontological approach to universal human rights, I will argue in agreement with Hoppe that the presuppositions implied by argumentation provide the basis for one's right to his own body and justly acquired property. The first section establishes the neo-Kantian analytical framework employed in the following two sections. These sections address self-ownership and ownership of property respectively. The fourth section works out the implications of the previous sections and asserts a radical imperative that the individual person never initiate force against another. Accordingly, the paper defends the position that force never be initiated for the appropriation of wealth.

\section{Pure Reason and the Implications of Action}

Hans-Hermann Hoppe can comfortably be considered one of the most prominent philosophers of libertarian ethics in the world today. His argument for an a priori system of deontological social ethics has been heavily debated in the libertarian literature for over two decades. ${ }^{1}$ Hoppe's a priori approach to ethics is an extension of economist Ludwig von Mises'

\footnotetext{
${ }^{1}$ Murphy and Callahan, 2006; Block, 2011; Kinsella, 1996. Also see the November 1988 issue of Liberty for a symposium entitled "Breakthrough or Buncombe?" on the subject of Hoppe's theory by the leading libertarian scholars of the time.
}

The Agora: Political Science Undergraduate Journal Vol. 3 No. 2 (2013) 
neo-Kantian method of social science. This approach uses pure reason to arrive at irrefutable propositions, the implications of which form the basis of man's knowledge. While Kant and Mises largely agreed upon the content of this knowledge---in Kant's terminology the "categories of the understanding" ---Mises provides a critical missing link in Kantian epistemology by recognizing that the categories of the understanding are categories of action.

To understand what this means and how Mises accomplishes this revolutionary task, let us first consider Kantian epistemology as such, since many readers may understandably be unfamiliar with the Critique of Pure Reason. Kant's theory of knowledge rests on the idea that reality must conform to the structure of the human mind. The apparent necessity of time and space, for instance, does not mean that reality itself is spatiotemporal, but that the mind conditions one's experience of reality in this way. To use an analogy, consider the shape that a column of water makes in a beaker. From the beaker's point of view, one of water's qualities is its cylindrical shape. That this is clearly not the case is known to us because of our ability to see water as it is.

Yet man is not afforded this luxury with regards to reality. Kant's project is to identify the contours of the structure of the mind that condition our experience of reality. These fundamental concepts of thought are the above-mentioned categories. It is not necessary for our present purposes to elaborate upon Kant's method of deducing these categories or the list of categories he claims to have deduced. It will be sufficient to acknowledge that his method of deduction has been widely questioned by philosophers representing a great multitude of persuasions.

Writing a century and a half after the Critique of Pure Reason was first published, Mises succeeded where Kant failed. As an economist, Mises was concerned with individual human action and its implications. At the center of Mises' approach to social science was the apodictically certain axiom that humans act. "Action" is defined as purposeful behavior. It is more than mere bodily movement. ${ }^{2}$ In acting, an individual employs means to attain a subjectively valued end. He or she acts in order to substitute a less suitable state of affairs for a more preferred state of affairs. Indifference at the level of action is a meaningless concept as, in acting, man foregoes one possible end in pursuit of another. ${ }^{3}$ This process is always future oriented. Man acts expecting that his means will bring about a certain end at a temporally later point. Thus implied in the fundamental axiom of action are the categories of time, causality, profit, loss, value, means, ends, choice, and preference. ${ }^{4}$

These categories are necessarily presupposed in every action. ${ }^{5}$ To say that action implies that these categories are logically necessary simply means that by introspective reflection upon action, one can deduce certain apodictically certain categories of action in accordance with the logical structure of the mind. ${ }^{6}$ The statement "humans act" cannot be refuted without violating the law of non-contradiction by performative contradiction. ${ }^{7}$ In order to deny that man acts, man must act. Thus prior to any empirical observation, we can arrive at ampliative knowledge about man: he acts. Consequently, the axiom can be considered a priori. From this necessarily true proposition follows directly the subsidiary categories enumerated above. Because these

\footnotetext{
${ }^{2}$ Mises 1998, p. 11.

${ }^{3}$ Hulsmann 1999, pp. 6-8; Block 1999, pp. 22-26; Rothbard 2011, pp. 304-306; Hoppe 2005.

${ }^{4}$ Hoppe 1995, p. 24; Rothbard 2009, pp. 4-7.

${ }^{5}$ Mises 2006, p. 10.

${ }^{6}$ Previous ambiguity regarding the term "imply" has been a point of criticism. See Smith, 1990.

${ }^{7}$ Hoppe 1995, p. 22.
}

The Agora: Political Science Undergraduate Journal Vol. 3 No. 2 (2013) 
categories are deduced from the action axiom without any recourse to empirical inquiry, they too are true a priori. ${ }^{8}$

By a priori, I refer to that knowledge which is obtained via pure reason. Of course, the psycho-physical process of discovering a priori knowledge must involve data collected by the senses. What differentiates a priori knowledge from a posteriori knowledge is not that it occurs in a sensory vacuum but that it is necessarily true and unfalsifiable. ${ }^{9}$

Mises' utilized the a priori knowledge of action primarily as a method for analyzing human action in a value-free manner. At this, he was quite successful, resuscitating the Austrian school economics from the vitiation it suffered in the generations after its founding in the 1870s. ${ }^{10}$ This achievement was due in large part to Mises' philosophical foundation, the implications of which should have spawned a renaissance in neo-Kantian philosophy. Yet Mises treated his brilliant philosophical insights as something of an afterthought. The task of unpacking Mises' philosophy was thus left to Hans-Hermann Hoppe. Hoppe works out the implied ethical axioms in Mises' action axiom which ostensibly establish an a priori basis for universal human rights.

\section{Self-Ownership}

Hoppe observes that argumentation is a subcategory of action. As has been shown, it is impossible for man to deny that men act because to do so would result in an illogical performative contradiction. It is similarly nonsensical for a man to argue that men do not argue. ${ }^{11}$ Moreover, unless one presupposes argumentation, there can be no concept of right, wrong, or true. ${ }^{12}$ Without argumentation as a category of action, what appears to us as language would be purposeless noise entirely devoid of truth-values.

For man to argue, he must further presuppose a right to argue inasmuch as he takes control of his mind, lungs, throat, larynx, and mouth. If taking possession of one's own bodily organs in order to argue were unethical, then the source of ethics must not only exist outside of our cognitive capabilities, but outside the realm of true and false since argumentation is the only method of ascertaining truth. In other words, in order to enter into inquiry concerning the rights of man, one must have a right to use all necessary human faculties. Since argumentation is an epistemologically necessary category, it applies to all human beings. This universality logically extends to the right of self-ownership, which is derived from argumentation.

To buttress this claim of necessary individual self-ownership, consider the logically possible arrangements of the ownership of men identified by Murray Rothbard. The only three possible arrangements are: (1) all men own all men; (2) some men own others; (3) man owns himself. ${ }^{13}$ Considering the first arrangement, an obvious question arises: how could any man ever act? If all men own all others, no man could ethically act to grant permission to another man so that that man could ethically approve of the initial action. Despite its egalitarianism, the proposition is frankly impossible. The second arrangement fails to stand up to the requirements of the crucial categorical imperative; its implied ethical maxim is not universal. In other words, there is no a priori way of determining who owns whom. Moreover, such an arrangement

\footnotetext{
${ }^{8}$ For a perspective on deduction of categories in general, see Guyer 2010.

${ }^{9}$ Mises 2006, p. 15.

${ }^{10}$ Salerno, 1999

${ }^{11}$ Hoppe, 1988a, pp. 20-22

${ }^{12}$ Hoppe, 2006, p. 371

${ }^{13}$ Rothbard 1982, pp. $47-48$
}

The Agora: Political Science Undergraduate Journal Vol. 3 No. 2 (2013) 
(slavery by any other name) is offensive to our ethical intuition, a critical though informal test of any ethical theory. ${ }^{14}$ Thus we are left with only one possible arrangement: man owns himself.

Let us briefly consider some objections to Hoppe's theory of self-ownership. One criticism is that Hoppe has only demonstrated limited dominion over man's body and that even then that he is only a self-owner during the course of the debate. ${ }^{15}$ Walter Block responds to this first objection by noting the holism of the human body. If one appears to only use six or seven organs while uttering a proposition, removing another organ still violates self-ownership. ${ }^{16}$ Since the brain is necessarily involved in argumentation and the removal of a foot disturbs the brain via the nervous system, this is a form of encroachment upon self-ownership. While Block has made no error in response to this criticism, it is more logically satisfying to refute this critique of Hoppe by observing, as we have, that there exists no feasible property arrangement other than self-ownership.

Regarding the criticism that man owns himself only during the course of debate, we must distinguish between the a priori category of argumentation and the process of argumentation. While Hoppe repeatedly makes argumentation the source of natural rights, the physical act of argumentation is not necessary any more than one needs to constantly draw right triangles for the Pythagorean theorem to be valid. Similarly, the non-obvious but a priori right to self-ownership implied by the act of argumentation need not be continually tested; its truth is apodictically and immutably certain in accordance with the rational structure of the mind. To recognize this, one must not focus on two individuals talking but on the concept of argumentation itself. This is analogous to considering the abstract definition of a right triangle rather than a particular drawing.

One way of "proving" that the category of argumentation is a priori is to consider the impossibility of its negation. Perhaps a more definitive way of proving its concreteness is to establish the concept of truth as essential for action. As Mises recognizes, essential to action is that it is driven by the desire to achieve ends. The selection of means requires a normative judgment about what is the best means of achieving a given end. This implies knowledge, which presupposes a concept of truth. Since action is a priori and truth is necessary for action, it follows that truth, as a category, is a priori. Since the a priori category of truth is inseparable from the concept of argumentation, the category of argumentation must too be a priori.

\section{Ownership of Objects}

Hoppe continues his argument by extending self-ownership to the ownership of objects:

"[If] no one had the right to control anything at all except his own body, then we would all cease to exist and the problems of justifying norms simply would not exist. Thus by virtue of the fact of being alive, property rights to other things must be presupposed to be valid. No one who is alive could argue otherwise."17

Here Hoppe claims that argumentation implies recognition of the human right to occupy finite space and eat food. In order to prolong one's life, property is essential. If man cannot own food,

\footnotetext{
${ }^{14}$ See Lewis, 2001

${ }^{15}$ Murphy and Callahan, 2006, pp. 55-59; Waters, 1988, p. 47.

${ }^{16}$ Block, 2011, p. 83

${ }^{17}$ Hoppe, 1998a, p. 20
}

The Agora: Political Science Undergraduate Journal Vol. 3 No. 2 (2013) 
a scarce resource, how could he justifiably destroy it in the process of consumption? Robert LeFevre also recognizes this, noting, "A property-less living organism is inconceivable.""18

The method of appropriating this necessary space and nourishment is homesteading action, "establishing a link between a particular person and a particular scarce resource before anybody else has done so." Since argumentation is an activity that an individual, temporal human being engages in, homesteading is also an individual temporal activity. This is the basis for individual ownership of property.

Again, let us consider alternative property arrangements. There are three possible property arrangements for the ownership of items in use by human beings: (1) Property is owned in common; (2) Some individuals own property; (3) All individuals own property. ${ }^{20}$ The first arrangement has received considerable attention from contemporary scholars. While total collective ownership has seen diminishing popularity as a theory of resource allocation, collective ownership of so-called "public goods" remains a popular line of thought in both economics and political philosophy. The problem with collective ownership, in any degree and for any reason, is its impossibility.

Collective ownership is a property arrangement in which property is owned socially. All persons in society are equal co-owners of public goods. The fatal flaw with this egalitarian arrangement is that the private citizen is merely a nominal co-owner of goods controlled by others. As Hoppe notes, "Declaring everybody a co-owner of everything solves the problem of differences in ownership only nominally. It does not solve the real underlying problem: differences in the power to control." 21

The problem of making decisions regarding the property owned in common cannot be solved by appealing to the unit who is said to claim ownership over the item in question, namely, "society." It is now widely accepted in political science and economics that groups do not act. When one does away with the practice of reifying society and examining the actors who make up the group, two possible property arrangements emerge. The first arrangement is one in which common goods are not in fact common but financed socially and controlled privately by individuals. This is the arrangement we often see in practice. The state or the corporations allied to it are the real controlling owners of collective goods. This arrangement is one in which only some individuals own property. ${ }^{22}$ But who is the special class that is allowed to own property? This arrangement fails because of its moral and practical arbitrariness.

The other possible solution to the problem of control of collective goods is to claim that all citizens have an equal share of ownership. This arrangement, while rare in practice, resembles a joint stock company in which an individual is the absolute owner over a share or a number of controlling shares in a company. The primacy of individual ownership is obvious. In order to solve the problems raised by collective ownership, an appeal must necessarily be made

\footnotetext{
${ }^{18}$ LeFevre, 1966, p. 3

${ }^{19}$ Hoppe, 1988a, 21

${ }^{20}$ F.A. Harper presents a similar set of arrangements in Liberty: A Path to Its Recovery. His categories concern production however, and thus presuppose the ownership of homesteaded natural objects. Rothbard also enumerates a similar list in The Ethics of Liberty.

${ }^{21}$ Hoppe, 2010, pp. 36-37

${ }^{22}$ Note that this is an a priori claim rather than an empirical or practical claim. In a society built upon the defendable a priori claim that "individuals own property," the practical result may be that a handful of unlucky men own very little or even no property. This does not mean that the indefensible a priori arrangement that "some men own property" is anything but fallacious.
}

The Agora: Political Science Undergraduate Journal Vol. 3 No. 2 (2013) 
to private ownership. Thus we see that the only possible and only moral property arrangement is the individual ownership of property defended by Hoppe. ${ }^{23}$

\section{Rights and Equality}

We have now sufficiently demonstrated an a priori social ethic for man. This ethical system gives man a right to self-ownership and ownership of justly acquired property. From these rights emerge two imperatives: do not aggress against another man and do not aggress against another man's property. These fit with both the categorical imperative and the important informal test against our moral tradition. ${ }^{24}$

We are now finally prepared to address the issue in question: the fairness of income inequality. To judge the fairness of any social phenomenon we must examine the human action that causes it. Human action is essential to all questions of fairness since non-human natural phenomena cannot in any meaningful sense be morally evaluated. It is quite possible to claim, as some have, that the inequality of human talents is in unfair. ${ }^{25}$ However, such a claim does not have any real ethical meaning. Social ethics concerns man's actions, not the randomness of natural phenomena. Calling a natural state of affairs "unfair" is merely an appeal toward a subjective egalitarian ideal that has neither consequential nor deontological bearing in reality. ${ }^{26}$

In order for income inequality to be unfair, human action must make it so. According to man's right to his person and property, any action that violates these rights resulting in inequality is unfair. In order for an individual's income to be fair, it must be acquired through non-coercive means. This prohibition against coercion applies to all humans. It makes no difference whether an individual who acquires his income by coercive means commits aggression himself or enlists the help of another. In our present circumstances, there exists a great deal of unfair income inequality due to the grand apparatus of coercion that is the state. Taxation is an omnipresent manifestation of the state's monopoly on the use of force over a given geographical area. Rentseeking private corporations and recipients of welfare payments alike acquire income by unjust means thanks to the taxing power of the state.

The enormity and complexity of the modern welfare state, however, has led to profound ambiguity surrounding the beneficiaries and victims of institutionalized coercion. One cannot simply decry the millions of citizens who receive welfare payments while multimillionaires benefit from the same coercive apparatus. Neither can one also cast aspersion upon the pure size of another's income without demonstrating that it has been attained through unjust means. Income inequality should be treated as an unfair phenomenon due to the means by which it arises. Inequality as such is neither fair nor unfair; it is merely a historical datum. The human actions that lead to this datum are what must be analyzed to determine fairness. This is not to disregard the social and economic effects of income inequality. There may be demonstrable

\footnotetext{
${ }^{23}$ The line if argument I have presented here also strengthens Hoppe's position against critics who claim he has conflated use with ownership. See Douglas Rasmussen, "Arguing and Y-ing," Liberty, November 1988: 50-52.; Mitchell Jones, "A Matter of Degree," Liberty, November 1988: 49.; Murphy and Callahan, 2006 for such criticism. See Block, 2011; Hoppe, 1988b, "Utilitarians and Randians vs. Reason" for a response.

${ }^{24}$ See the appendix "Illustrations of the Tao" in C.S. Lewis, The Abolition of Man (New York, NY: HarperOne, 2001) for a cross-cultural survey of traditional ethics.

${ }^{25}$ See Rawls 1999.

${ }^{26}$ For a cogent refutation of Rawls' allegedly deontological concept of fairness, see Robert Nozick, Anarchy, State, and Utopia (New York, NY: Basic Books, 1974). While missing the mark with his own deontological theory of justice, Rawls was a strong and persuasive critic of consequentialist ethics. For an excellent summary of his critique, see David Lyons, "Rawls Versus Utilitarianism ," The Journal of Philosophy 69, no. 18 (1972): 535-545.
}

The Agora: Political Science Undergraduate Journal Vol. 3 No. 2 (2013) 
reasons to want income equality. The benefits and costs of a particular level of income distribution, however, should not be conflated with ethics.

\section{Conclusion}

According to the social ethic derived a priori by Hans-Hermann Hoppe, supported by the recognition of the implausibility of non-individual-centered property arrangements, man has absolute rights to his life and his justly acquired property. So long as neither of these rights is violated in the process of acquiring income, inequality of income is a fair phenomenon. In a society based on non-coercive mutual exchange income inequality, no matter how egregious, may be regarded as fair. Modern society, however, hardly resembles such a free and peaceful society due primarily to the state. Accordingly, the task of political philosophers and policymakers convinced by this approach to ethics is the working out of the practical implications of absolute rights in a society marked by pervasive coercion. 


\section{Bibliography}

Block, Walter. "Rejoinder to Murphy and Callahan on Hoppe's Argumentation Ethics." Journal of Libertarian Studies 22 (2011): 631-639.

—. "Austrian Theorizing: Recalling the Foundations." The Quarterly Journal of Austrian Economics 2, no. 4 (Winter 1999): 21-39.

Guyer, Paul. "The Deduction of the Categories." In The Cambridge Companion to Kant's Critique of Pure Reason, 118-151. New York: Cambridge University Press, 2010.

Hulsmann, Jorg Guido. "Economic Science and Neoclassicism." The Quarterly Journal of Austrian Economics 2, no. 4 (Winter 1999): 3-20.

Hoppe, Hans-Hermann. A Theory of Socialism and Capitalism. Auburn, AL: Ludwig von Mises Institute, 2010.

-. The Economics and Ethics of Private Property. Aubuern, AL: Ludwig von Mises Institute, 2006.

—."The Ultimate Justification of the Private Property Ethic." Liberty, September 1988a: 2022.

- "A Note on Preference and Indifference in Economic Analysis." The Quarterly Journal of Austrian Economics 8, no. 4 (Winter 2005): 87-91.

—."Utilitarians and Randians vs. Reason." Liberty, November 1988b: 53-54.

Jones, Mitchell. "A Matter of Degree." Liberty, November 1988: 49.

Kant, Immanuel. "Principles of Political Right." In Kant's Principles of Politics Including His Essay on Perpetual Peace: A Contribution to Political Science, by Immanuel Kant, edited by W. Hastie, translated by W. Hastie. Edinburgh, 1891.

Kinsella, Stephan. "New Rationalist Directions in Libertarian Rights Theory." Journal of Libertarian Studies 12, no. 12 (1996): 323-338.

LeFevre, Robert. The Philosophy of Ownership. Colorado Springs, CO: Rampart College Press, 1966.

Lewis, C.S. The Abolition of Man. New York, NY: HarperOne, 2001.

Lyons, David. "Rawls Versus Utilitarianism ." The Journal of Philosophy 69, no. 18 (1972): 535-545.

The Agora: Political Science Undergraduate Journal Vol. 3 No. 2 (2013) 
Mises, Ludwig von. Human Action: A Treatise on Economics. Auburn: Ludwig von Mises Institute, 1998.

—. The Ultimate Foundation of Economic Science. Indianapolis: Liberty Fund, 2006.

Murphy, Robert, and Callahan Gene. "Hans-Hermann Hoppe's Argumentation Ethic: A Critique." Journal of Libertarian Studies 20, no. 2 (2006): 53-64.

Nozick, Robert. Anarchy, State, and Utopia. New York, NY: Basic Books, 1974.

Rasmussen, Douglas. "Arguing and Y-ing." Liberty, November 1988: 50-52.

Rawls, John. A Theory of Justice. Revised Edition. Oxford: Oxford University Press, 1999.

Rothbard, Murray. "Beyond is and Ought." Liberty, November 1988: 44.

—. "Toward a Reconstruction of Utility and Welfare Economics." In Economic Controversies, 289-333. Auburn: Ludwig von Mises Institute, 2011.

—. Man, Economy, and State with Power and Market. 2nd ed. Ludwig von Mises Institute, 2009.

—. The Ethics of Liberty. Atlantic Highlands, NJ: Humanities Press, 1982.

Salerno, Joseph. “The Place of Mises's Human Action in the Development of Modern Economic Thought." The Quarterly Journal of Austrian Economics 2, no. 1 (1999): 35-65.

Smith, Barry. "The Question of Apriorism.” The Austrian Economics Newsletter (Fall 1990): 15.

Waters, Ethan. "Beyond is and Nought." Liberty, November 1988: 47.

The Agora: Political Science Undergraduate Journal Vol. 3 No. 2 (2013) 